Jurnal Perikanan (2021) Volume 11. No. $1: 13-25$

DOI : https://doi.org/10.29303/jp.v11i1.184

\title{
POTENSI PEMANFAATAN DAUN SINGKONG (Manihot utilissima) TERFERMENTASI SEBAGAI BAHAN PAKAN UNTUK MENINGKATKAN PERTUMBUHAN IKAN MAS (Cyprinus carpio)
}

\section{POTENTIAL UTILIZATION OF FERMENTED Cassava (Manihot utilissima) LEAVES AS FEED INGREDIENTS TO INCREASE GROWTH OF Carp (Cyprinus carpio)}

\author{
Alfirah Nurulaisyah ${ }^{1 *}$, Dewi Nur'aeni Setyowati ${ }^{1)}$, Baiq Hilda Astriana ${ }^{2)}$ \\ ${ }^{1)}$ Program Studi Budidaya Perairan Universitas Mataram, ${ }^{2)}$ Program Studi Ilmu Kelautan \\ Universitas Mataram \\ Jl. Pendidikan No. 37 Mataram, NTB \\ *Alamat Korespondensi: alfirahnurulaisyah45@gmail.com.
}

\begin{abstract}
Abstrak
Penelitian ini bertujuan untuk meganalisis pengaruh penambahan tepung daun singkong terfermentasi dalam pakan buatan terhadap pertumbuhan ikan mas serta konsentrasi optimum untuk menghasilkan pertumbuhan dan tingkat kelangsungan hidup yang tinggi bagi ikan mas. Metode yang digunakan pada penelitian ini adalah metode eksperimental dengan Rancangan Acak Lengkap (RAL) dengan menggunakan 5 perlakuan dan 3 kali ulangan. Perlakuan yang dicobakan adalah penambahan tepung daun singkong terfermentasi sebanyak 10\%, 15\%,20\%, 25\% dan $0 \%$ tanpa fermentasi daun singkong. Parameter yang diamati pada penelitian ini yaitu laju pertumbuhan mutlak, laju pertumbuhan spesifik, kelangsungan hidup (SR), rasio konversi pakan dan efisiensi pakan. Hasil analisis sidik ragam (ANOVA) pada pertumbuhan mutlak dan laju pertumbuhan spesifik berbeda nyata/signifikan $(\mathrm{P}<0,05)$, dan memberikan pengaruh yang tidak berbeda nyata/ tidak signifikan $(\mathrm{P}>0,05)$ pada Survival rate, Rasio Konversi Pakan dan Efisiensi Pakan.
\end{abstract}

Kata kunci: Daun Singkong, Fermentasi, Ikan Mas.

\begin{abstract}
This study heads to analyze the effect of adding fermented cassava's leaf flour in artificial feed on the growth of carp and optimum concentration to produce growth and a high survival rate for carp. The method used in this study is an experimental method with a Completely Randomized Design (CDR) using 5 treatments and 3 replications. The treatment that was tried was the addition of fermented cassava leaf flour by $10 \%, 15 \%, 20 \%, 25 \%$ and $0 \%$ without fermentation of cassava leaves. The parameters observed in this study were absolute growth rate, specific growth rate, survival rate (SR), feed conversion ratio and feed efficiency. The results of analysis of variance (ANOVA) on absolute growth and specific growth rate differ significant $(\mathrm{P}<0,05)$ and give no significant difference $(\mathrm{P}>0,05)$ on survival rate, Feed Conversion Ratio and Food Efficiency.
\end{abstract}

Keywords : Cassava, Fermentation, Cyprinus carpio. 
Jurnal Perikanan (2021) Volume 11. No. 1 : 13-25

DOI : https://doi.org/10.29303/jp.v11i1.184

\section{PENDAHULUAN}

Ikan mas (Cyprinus carpio) merupakan jenis ikan bernilai ekonomis, karena sudah memasyarakat dan tersebar hamper diseluruh provinsi di Indonesia dan telah menjadi sumber mata pencahriaan masyarakat padadaerah tertentu, seperti Jawa Barat, Sumatera Barat, Sumatera Utara, Sulawesi Utara dan Sulawesi Tengah (Khairul Saleh et al., 2014). Permintaan terhadap produk ikan mas cukup besar dan menjadikan ikan mas sebagai salah satu ikan favorit masyarakat Indonesia. Keunggulan ikan mas bagi para petani antara lain, mudah dipelihara, pertumbuhannya relatif cepat, jumlah telur yang dihasilkan tergolong tinggi dan pemakan segala. Selain itu harga ikan mas tidak terlalu mahal, artinya dapat terjangkau oleh semua golongan. Harga ikan mas pada umumnya Rp. $30.000 / \mathrm{kg}$, harga ini merupakan patokan harga dari Kabupaten Lombok Barat (Rika et al., 2016). Oleh sebab itu, tidak mengherankan apabila ikan mas termasuk salah satu komoditas unggulan di sektor perikanan air tawar (Khairuman et al., 2001).

Ikan mas (Cyprinus carpio) banyak dikonsumsi karena rasanya yang enak, gurih dan mempunyai kandungan gizi yang tinggi. Berdasarkan data yang diperoleh dari Direktorat Gizi Departemen Kesehatan RI (1981), ikan mas mengandung protein 4,5 gram, karbohidrat 23,1 gram; dan lemak 0,2 gram. Selain itu ikan mas mengandung kalori (kal) 86, fosfor (P) $134 \mathrm{mg}$, kalsium (Ca) 42 $\mathrm{mg}$, besi (Fe) $1 \mathrm{mg}$, Vitamin B1 0,22 mg dan air sebanyak $71 \mathrm{mg}$ /ekor. Tidak mengherankan bila minat masyarakat untuk mengkonsumsi ikan mas semakin meningkat seiring dengan peningkatan taraf hidup masyarakat (Hardjamulia, 1988).

Sebagaiupaya memenuhi permintaan masyarakat maka dilakukan kegiatan budidaya ikan mas. Kegiatan budidaya tidak terlepas dari resiko biologis terutama yang disebabkan oleh adanya gangguan penyakit yang dapat menyebabkan menurunnya tingkat produksi ikan. Masalah lain seperti kualitas air yang menurun akibat pencemaran, tingkat pengetahuan dan keterampilan pembudidayaan ikan yang masih rendah, dan juga pengelolaan pakan yang kurang efektif. Menurut Priyadi et al. (2009), pakan memiliki biaya operasional yang cukup tinggi yaitu 60\%-70\%, dimana dalam sebagian besar upaya pemenuhan kebutuhan protein pakan disuplai dari penggunaan tepung ikan (Yudhitstira et al.,2015).

Pakan menjadi salah satu faktor penting yang berpengaruh terhadap pertumbuhan dan kelangsungan hidup ikan yang akan dibudidayakan. Di dalam pakan harus terkandung nutrisi yang memenuhi kebutuhan ikan seperti karbohidrat, protein dan lemak serta beberapa mineral. Ikan lebih banyak menggunakan protein sebagai sumber energi utama dibanding karbohidrat, sehingga pada formulasi pembuatan pakan hal utama yang harus di perhatikan adalah kandungan proteinnya. Menurut Handajani et al., (2014), kebutuhan protein dalam pakan antara spesies ikan sangat berbeda dan pada umumnya berkisar antara 20\%-60\%.

Sehubungan dengan penyediaan pakan, komposisi ransum dan kandungan nutrisi pada pakan ikan dapat meningkatkan efisiensi pemanfaatan pakan. Artinya semakin tercukupi kebutuhan nutrisi pakan maka tingkat produksi ikan semakin tinggi dan besar keuntungan yang dicapai. Pengaturan nutrisi pada ikan budidaya berkaitan dengan pentingnya mengubah kapasitas pencernaan ikan, seperti kemampuan untuk meningkatkan kecernaan karbohidrat dan protein nabati. Selain itu, ketersediaan pakan dalam jumlah yang cukup, tepat waktu, dan bernilai gizi baik merupakan salah satu faktor yang sangat penting dalam kegiatan usaha budidaya perikanan. Kendala yang selalu dialami oleh para pembudidaya adanya bahan baku tepung ikan yang masih terbilang mahal. 
Berdasarkan hal tersebut, diperlukan upaya penggunaan bahan alternatif untuk pembuatan pakan yang berasal dari lokal, mempunyai nilai nutrisi yang baik, bermanfaat untuk pertumbuhan ikan mas, murah serta mudah didapat. Salah satu bahan alami yang dapat dimanfaatkan adalah daun singkong (Manihot utilissima).

Daun singkong merupakan sumber daya hayati yang berpotensi sebagai bahan baku pakan ikan. Daun ini memiliki kandungan nutrisi yang cukup tinggi yaitu bahan kering $23,36 \%$; protein kasar 29\%; serat kasar 19,06\%; lemak 9,41\%; bahan ekstrak tanpa nitrogen (BETN) 34,08\%; abu 8,83\%. Kandungan nutrisi daun singkong ini setara dengan bahan baku alternatif sumber protein lainnya seperti DDGS (Dried Distillers Grains with Solubles hasil produksi ethanol), tepung daun lamtoro dan lainnya. Menurut Samsugiantini (2006), daun singkong mengandung flavonoid yang bermanfaat untuk meningkatkan nafsu makan. Selain itu daun singkong memiliki kandungan vitamin A, B1 dan $\mathrm{C}$ yang cukup tinggi serta mengandung kalsium, fosfor dan zat besi (Amarwati et al., 2015).

Penambahan hasil fermentasi tepung daun singkong dalam pakan dapat meningkatkan kandungan nutrisi khususnya menurunkan kandungan serat kasar sehingga dapat meningkatkan pertumbuhan ikan. Penelitian mengenai fermentasi tepung daun singkong sudah pernah dilakukan sebelumnya untuk ikan nila (Amarwati et al., 2015 dan Listiowati et al., 2014). Berdasarkan hasil penelitian Listiowati (2014), penambahan fermentasi tepung daun singkong sebanyak $25 \%$ memberikan pertumbuhan terbaik untuk ikan nila. Akan tetapi sejauh ini, studi literatur yang telah dilakukan menunjukkan bahwa penelitian mengenai dosis optimum tepung daun singkong terfermentasi yang diaplikasikan pada pakan buatan untuk ikan mas (Cyprinus carpio) belum dilakukan.
Berdasarkan latar belakang ini maka perlu dilakukan penelitian tentang penggunaan tepung daun singkong terfermentasi sebagai bahan pakan ikan mas (Cyprinus carpio).

\section{METODE PENELITIAN}

\section{Alat dan Bahan}

Alat-alat yang digunakan dalam penelitian ini adalah Kontainer, Ayakan, seser, pengaduk, baskom, timbangan digital, kamera, blender, pisau, alat pencetak pellet, kertas label, jaring, kompor, selang aerasi, selang air, toples, panic,erator, suhu, $\mathrm{pH}$ meter dan DO meter.

Bahan yang digunakan dalam penelitian ini adalah Ikan Mas, tepung Daun Singkong, tepung ikan, tepung jagung, tepung tapioca, dan probiotik EM4.

Rancangan penelitian yang digunakan adalah Rancangan Acak Lengkap (RAL) dengan menggunakan 5 perlakuan dan 3 kali ulangan. Perlakuan yang dicobakan adalah penambahan tepung daun singkong terfermentasi sebanyak $10 \%, 15 \%, 20 \%$ dan $25 \%$, dengan mengurangi pakan sebanyak tepung daun singkong yang terfermentasi.

\section{Persiapan Penelitian}

Tahapan persiapan penelitian meliputi kegiatan

\section{a. Persiapan Bahan Baku Pakan}

1. Pembuatan Tepung Daun Singkong

Bagian tanaman yang digunakan adalah daun singkong. Daun singkong dicuci dan dipotong/gunting menjadi bagian kecil dengan ukuran 2-3 cm. Kemudian daun singkong dikeringkan dibawah sinar matahari selama 3-4 hari. Setelah itu daun singkong dihaluskan dengan menggunakan blender dan diayak. ( Listiowati et al., 2014 )

\section{Fermentasi Tepung Daun Singkong}

Tepung daun singkong yang telah dihaluskan dan diayak, ditimbang kembali sebanyak 1000 g. Setelah ditimbang tepung daun singkong dikukus dengan menggunakan panci selama 30 menit. Setelah selesai dikukus, tepung daun singkong didinginkan. Setelah 
didinginkan tepung daun singkong ditimbang sebanyak $200 \mathrm{~g}$ dan dicampur secara homogen dengan EM4 sebanyak 10\% dari berat tepung daun singkong (Listiowati, 2014).

Campuran tepung dan EM4 dimasukkan ke dalam kantong plastik yang berukuran $14 \mathrm{~cm}$ x $30 \mathrm{~cm}$. Setelah itu campuran dimasukkan pada toples tertutup rapat dan difermentasi selama 7 hari. Tepung daun singkong yang telah difermentasi diangkat dan dikeringkan selama 1 hari dibawah sinar matahari (Handajani, 2007 dengan modifikasi).

\section{Pembuatan Pakan}

Bahan pakan uji terdiri dari tepung ikan, tepung jagung, tepung tapioka dan tepung daun singkong yang telah difermentasi menggunakan EM4. Bahan-bahan tersebut sebelum diformulasikan terlebih dahulu dilakukan analisis proksimat yang berguna untuk menyesuaikan dengan komposisi dan formulasi pakan yang akan dibuat (Listiowati, 2014).

Analisis proksimat meliputi kadar air, kadar abu, protein, lemak dan serat kasar. Hasil analisis proksimat bahan-bahan penyusun pakan. Setelah diketahui hasil analisis antara bahan baku pakan lalu dimasukan ke dalam formula pakan.

\section{b. Persiapan Wadah Pemeliharaan}

- Pemeliharaan ikan mas dilakukan secara outdoor pada wadah berupa kontainer berkapasitas 50 liter sebanyak 15 kontainer.

- Kontainer, selang aerasi, batu aerasi, seser dan peralatan lainnya dicuci bersih sebanyak dua kali untuk menghilangkan debu atau kotoran yang menempel. Kemudian kontainer diisi air sebanyak 40 liter yang diberi aerasi. Air yang digunakan adalah air sumur dan didiamkan selama 2 hari, agar partikel yang terlarut dapat mengendap dan gas beracun dapat menguap.

\section{c. Persiapan Ikan Uji}

- Ikan yang digunakan dalam penelitian ini adalah ikan mas yang memiliki berat $10 \mathrm{~g}$ sebanyak 150 ekor yang diperoleh di wilayah Lingsar, ikan yang digunakan sehat, gerakan lincah dan tidak cacat. Ikan ditebar sebanyak 10 ekor/40 liter (perunit percobaan).

- Ikan mas terlebih dahulu dilakukan pengadaptasiaan selama 7 hari untuk menyesuaikan diri terhadap temperatur dari lingkungan barunya serta di lakukan pemberian pakan tenggelam dan dipuasakan terlebih dahulu selama satu hari. Ikan mas sebelum ditebar ke masingmasing wadah pemeliharaan, diseleksi terlebih dahulu dengan cara ditimbang dengan menggunakan timbangan digital untuk mengetahui bobot awal ikan yang akan ditebar.

\section{d. Penebaran Ikan Mas}

- Ikan mas diseleksi terlebih dahulu, kemudian ikan ditebar pada 15 Kontainer yang berkapasitas 50 liter dalam 1 Kontainer ditebar sebanyak 10 ekor/ 40 liter air.

- Masing-masing kontainer diisi dengan 10 ekor ikan mas yang telah ditimbang berat tubuh dengan nilai sebesar 10 gram dan digunakan sebagai berat awal (Wo).

\section{e. Pemberian Pakan.}

- Pakan yang diberikan selama penelitian sebanyak 5 gram/hari untuk tiap kontainer dengan frekuensi pemberian pakan sebanyak 3 kali sehari yaitu pukul 08.00 pagi, 14.00 siang, 20.00 malam.

- Penyiponan sisa feses dan pakan yang tidak termakan dilakukan 2 hari sekali yaitu dilakukan pada pagi hari. Lalu dilakukan pergantian air sebanyak $90 \%$ dari volume total tiap kontainer.

- Data penunjang kualitas air dianalisis secara deskriptif. Pengukuran kualitas air perlu dilakukan untuk mengetahui kondisi 
Jurnal Perikanan (2021) Volume 11. No. 1 : 13-25

DOI : https://doi.org/10.29303/jp.v11i1.184

air pada saat penelitian. Pengukuran kualitas air dilakukan pada awal penelitian dan di akahir penelitian, parameter yang diukur meliputi suhu, $\mathrm{pH}$,dan DO.

\section{Parameter Uji}

Parameter yang diuji dalam penelitian ini yaitu pertumbuhan mutlak, laju pertumbuhan spesifik, kelangsungan hidup, rasio konversi pakan, dan efisiensi pakan.

1. Pertumbuhan Mutlak

Pertumbuhan mutlak dihitung berdasarkan rumus dari Tian Qin (2003) dalam Listiowati dan Pramono (2014) sebagai berikut:

$$
\mathrm{PM}=\mathrm{Wt}-\mathrm{Wo}
$$

Keterangan :

PM : Pertumbuhan Mutlak (g)

Wt : Bobot ikan pada akhir penelitian $(\mathrm{g})$

Wo : Bobot ikan pada awal penelitian (g)

\section{Laju Pertumbuhan Spesifik (LPS)}

Pertumbuhan berat sebagai data pertumbuhan ikan yang diukur tiap 7 hari sekali untuk mengetahui pengaruh dari pemberian pakan daun singkong untuk meningkatkan pertumbuhan ikan mas. Pertumbuhan spesifik dihitung berdasarkan rumus dari Huisman (1987) dalam Haris (2010) :

$L P S=\frac{\text { InWt }- \text { InWo }}{\mathrm{T}} \times 100 \%$

Keterangan :

LPS : Laju pertumbuhan Spesifik (\%/hr)

$\mathrm{Wt}$ : Bobot ikan pada akhir penelitian (g)

Wo : Bobot ikan pada awal penelitian $(\mathrm{g})$

$\mathrm{T}$ :Jumlah hari pemeliharaan (hari)

\section{Survival rate (SR)}

Adalah kelangsungan hidup ikan mas dalam suatu proses budidaya dari mulai awal ikan ditebar hingga ikan dipanen. SR meliputi baik faktor biotik maupun abiotik yang mempengaruhi tingkat kelangsungan hidup ikan. Kelangsungan hidup (Survival rate) dihitung berdasarkan rumus dari Effendie (2002) dalam Amarwati et al. (2015) :

$\mathrm{SR}=\frac{N t}{N o} \times 100 \%$

Keterangan :

SR : Survival rate (\%)

$N t$ : Jumlah ikan yang hidup pada akhir pemeliharaan (ekor)

$N_{0} \quad$ : Jumlah ikan pada awal penebaran (ekor)

4. Rasio Konversi Pakan (RKP)

Parameter dalam menunjukkan keefisienan dalam pemberian pakan selama penelitian. Konversi pakan dihitung berdasarkan rumus dari Tacon (1997) dalam Fadri et al. (2016) :

$\mathrm{RKP}=\frac{\mathrm{F}}{\mathrm{Wt}-\mathrm{Wo}_{\mathrm{o}}}$

Keterangan :

RKP : Rasio Konversi Pakan

F : Pakan yang diberikan (g)

Wt : Bobot ikan pada akhir penelitian

Wo : Bobot ikan pada awal penelitian (g)

\section{Efisiensi Pakan (EP)}

Perbandingan antara pertambahan bobot tubuh yang dihasilkan dengan jumlah pakan yang dikonsumsi selama pemeliharaan. Efisiensi pakan dihitung berdasarkan rumus dari Tacon (1987) dalam Amarwati et al. (2015) :

$\mathrm{EP}=\frac{\mathrm{Wt}-\mathrm{Wo}}{F} \times 100 \%$

Keterangan :

EP : Efisiensi pakan

Wt : Bobot ikan pada akhir penelitian (g)

Wo : Bobot ikan pada awal penelitian (g)

$\mathrm{F} \quad$ : Pakan yang diberikan $(\mathrm{g})$

6. Analisis Proksimat

a) Analisis Kandungan Protein Kasar (Purnamasari dan Dilaga, 2015)

Protein Kasar $=\frac{\text { ml titrasi } \times 0,1 \times 0,014 \times 6,25}{\text { berat sampel }} \times 100 \%$ 
b) Analisis Kandungan Serat Kasar (Purnamasari dan Dilaga, 2015)

$$
\text { Serat kasar }=\frac{B-C}{A} \times 100 \%
$$

c) Analisis Kandungan Air (AOAC, 1995)

Kadar air basah $(\mathrm{g} / 100 \mathrm{~g}$ bahan basah $)=$

$$
\mathrm{W}-\frac{(\mathrm{W} 1-\mathrm{W} 2)}{W} \times 100
$$

Kadar air kering (g/100 g bahan kering)

$$
=W-\frac{\mathrm{W} 1-\mathrm{W} 2}{\mathrm{WI}-\mathrm{W} 2} \times 100
$$

Keterangan :

$\mathrm{W}$ : Bobot sampel sebelum dikeringkan $(\mathrm{g})$

W1 : Bobot sampel dan cawan kering $(\mathrm{g})$

W2 : Bobot cawan kosong (g)

d) Analisis Kandungan Abu

$$
\mathrm{Abu}=\frac{W 3-W 1}{W 2-W 1} \times 100 \%
$$

Keterangan :

W1 : Bobot cawan kosong (g)

W2 : Bobot sampel sebelum dikeringkan (g)

W3 : Bobot sampel dan cawan kering

e) Analisis Kandungan Lemak (AOAC, 2005)

$$
\% \text { Lemak }=\frac{\mathrm{W} 3-\mathrm{W} 2}{\mathrm{~W} 1} \times 100
$$

Keterangan :

W1 : Bobot sampel (g)

W2 : Bobot lemak kosong (g)

W3 : Bobot lemak + lemak hasil ekstrak (g)

\section{Analisis Data}

Analisis data yang digunakan pada penelitian ini adalah Analysis of Variance (ANOVA) pada taraf nyata 5\%. Jika terdapat berbeda nyata dalam uji ANOVA maka dilakukan dengan uji Duncan untuk mengetahui perbedaan antara perlakuan.

\section{HASIL DAN PEMBAHASAN}

\section{Pertumbuhan Mutlak (PM)}

Pertumbuhan mutlak adalah pertambahan ukuran berat dalam suatu waktu (Efendi, 1997).

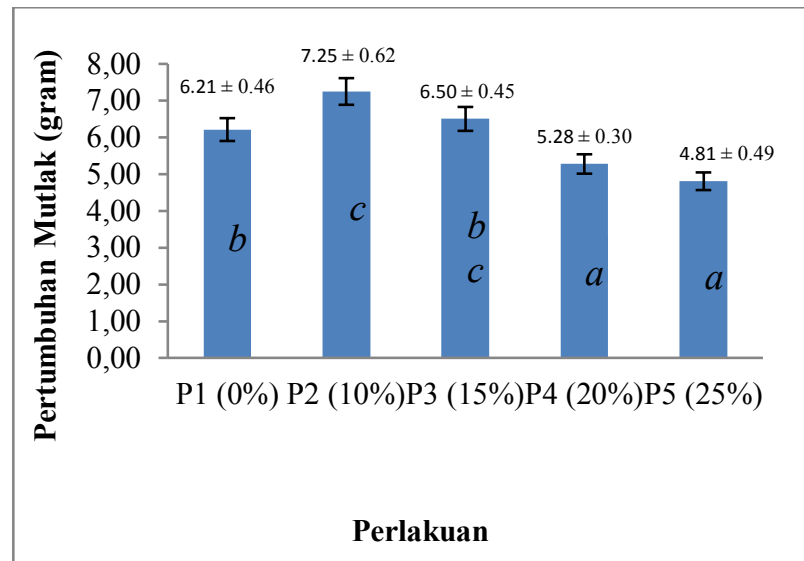

Gambar 1. Grafik Pertumbuhan Mutlak ikan mas (Cyprinus carpio)

Hasil analysis of variance (ANOVA) menunjukkan bahwa perlakuan menunjukkan adanya perbedaan yang signifikan pada nilai pertumbuhan mutlak antara perlakuan $(\mathrm{P}<0,05)$. Oleh karena itu dilakukan uji lanjut Duncan untuk mengetahui perbedaan setiap perlakuan.

Berdasarkan hasil hasil uji lanjut Duncan, pertumbuhan mutlak pada P1 $(0 \%)$ berbeda nyata dengan P2 (10\%), P4 (20\%) dan P5 (25\%). Sedangkan pertumbuhan mutlak yang paling tinggi pada P2 (10\%). Tingginya pertumbuhan mutlak pada perlakuan P2 dikarenakan jumlah tepung daun singkong yang digunakan tepat sehingga penambahan tepung tersebut sesuai dengan kebutuhan nutrisi ikan mas, sehingga pakan mudah dicerna dan serat kasar juga tidak terlalu banyak sehingga pertumbuhan mutlak pada ikan mas tinggi.

Rendahnya pertumbuhan mutlak pada perlakuan P3, P4 dan P5 pada grafik diatas bahwa semakin tinggi kandungan daun 
singkong didalam pakan ikan menyebabkan penurunan terhadap pertumbuhan ikan, hal ini dikarenakan serat kasar daun singkong yang cukup tinggi sehingga ikan sulit mencernanya dan proses pertumbuhan ikanmenurun, pemberian pakan daun singkong terfermentasi lebih dari $10 \%$ kurang bagus untuk pertumbuhan ikan mas. Sesuai dengan pernyataan oleh (Widjanarko et al., 2000) yang mengatakan bahwa meskipun daun singkong memiliki kandungan nutrisi tinggi, namun daun ini juga memiliki keterbatasan untuk dijadikan pakan ikan.

\section{Laju Pertumbuhan Spesifik (LPS)}

Laju pertumbuhan spesifik adalah panjang atau berat ikan yang dicapai pada suatu periode tertentu yang dihubungkan dengan panjang atau berat pada awal periode tersebut. Laju pertumbuhan spesifik pada penelitian ini dapat dilihat pada Gambar 2.

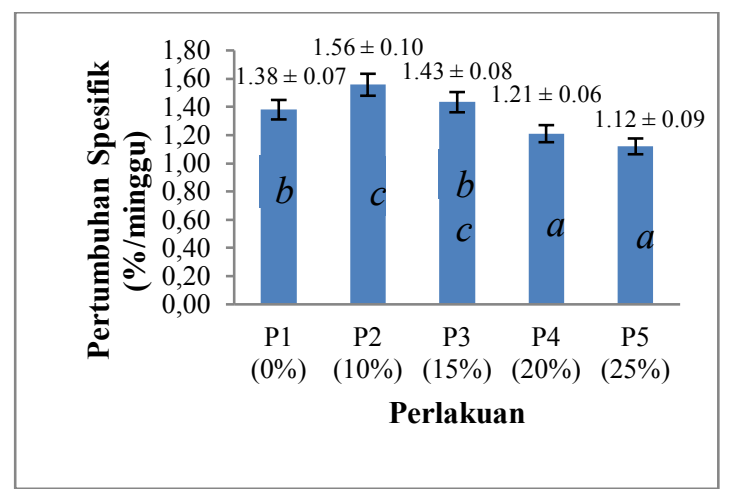

Gambar 2. Grafik Laju Pertumbuhan Spesifik ikan Mas (Cyprinus carpio)

Hasil analysis of variance (ANOVA) menunjukkan bahwa penambahan tepung daun singkong terfermentasi menunjukkan adanya perbedaan yang signifikan pada nilai laju pertumbuhan spesifik antara perlakuan $(\mathrm{P}<0,05)$. Oleh karena itu dilakukan uji lanjut untuk mengetahui perbedaan setiap perlakuan.

Berdasarkan hasil uji lanjut Duncan, pertumbuhan spesifik pada P1 $(0 \%)$ berbeda nyata dengan P2 (10\%), P4 (20\%) dan P5
(25\%). Sedangkan pertumbuhan spesifik yang paling tinggi pada P2 (10\%). Tingginya pertumbuhan spesifik pada perlakuan P2 dikarenakan jumlah tepung daun singkong yang digunakan tepat sehingga penambahan tepung tersebut sesuai dengan kebutuhan nutrisi ikan mas, sehingga pakan mudah dicerna dan serat kasar juga tidak terlalu banyak sehingga pertumbuhan spesifik pada ikan mas tinggi.

Rendahnya pertumbuhan spesifik pada perlakuan P4 dan P5 dikarenakan jumlah tepung daun singkong yang terlalu banyak menyebabkan kandungan serat kasarpada pakan tinggi sehingga sulit dicerna oleh ikan yang nantinya berakibat pada rendahnya konversi pakan pada ikan.

\section{Kelangsungan hidup (SR)}

Kelangsungan hidup merupakan suatu nilai perbandingan antara jumlah organisme awal saat penebaran yang dinyatakan dalam bentuk persen dimana semakin besar nilai presentase menunjukan semakin banyak organisme yang hidup selama pemeliharaan (Effendi, 2002).

Hasil analisis sidik ragam menggunakan analisis keragaman satu arah (one way anova) didapat nilai survival rate tidak menunjukan bahwa ada perbedaan nyata antara perlakuan $(p>0,05)$. Hal ini menunjukan bahwa penambahan tepung daun singkong terfermentasi memberikan hasil yang tidak signifikan terhadap kelangsungan hidup ikan mas, pemberian pakan terfermentasi daun singkong $5 \%, 10 \%, 15 \%, 20 \%$ dan $25 \%$ memberikan kelangsungan hidup yang sama dengan perlakuan tanpa pemberian daun singkong fermentasi $0 \%$, dari hasil rata-rata pada Gambar 7 menunjukan kelangsungan hidup yang optimal yaitu pada perlakuan $10 \%$ dan 15\% tetapi hasil uji ANOVA menunjukan semua tidak berbeda nyata antara perlakuan, sehingga pemberian pakan daun singkong terfermentasi hingga $25 \%$ dapat diberikan kepada ikan mas. 


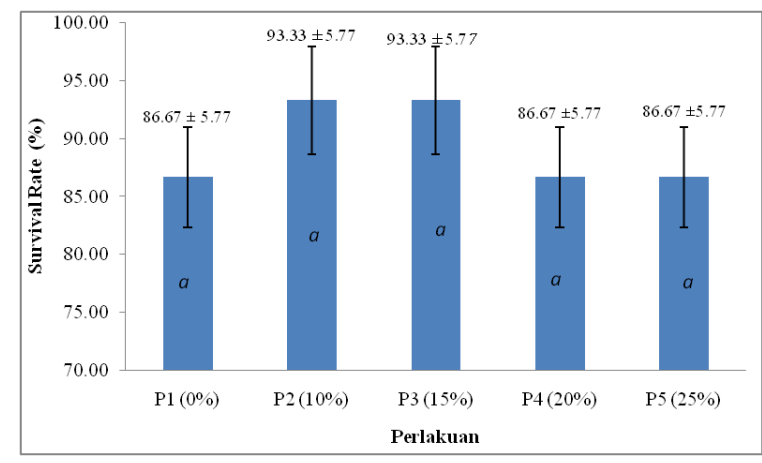

Gambar 3. Grafik Survival rate (SR) ikan mas (C.carpio).

\section{Rasio Konversi Pakan (RKP)}

Pakan merupakan bagian terbesar dari biaya produksi dan diduga juga merupakan faktor penentu dalam nilai ekonomi dari budidaya ikan.

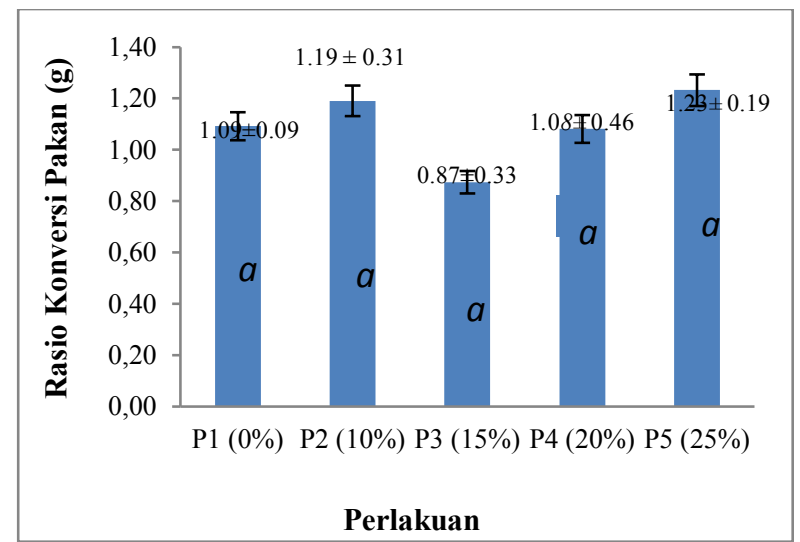

Gambar 4. Grafik Rasio Konversi Pakan Ikan mas (C.carpio)

Berdasarkan hasil analisis sidik ragam menggunakan analisis keragaman satu arah (one way anova), didapat nilai rasio konversi pakan tidak berbeda nyata dalam taraf kepercayaan 95\% (p>0,05). Hasil uji menunjukan bahwa penambahan tepung daun singkong terfermentasi memberikan hasil yang tidak signifikan terhadap rasio konversi pakan ikan mas, sehingga tidak diuji lanjut untuk mengetahui antara perlakuan.

Djangkaru 1991 dalam Widyastuti et al., 2010, menyatakan bahwa semakin kecil nilai RKP berarti pakan semakin berkualitas, hal ini menunjukan bahwa jumlah pakan yang dikonsumsi lebih besar pakan yang tersisa. Nilai RKP masih dianggap efisien apabila kurang dari 3, sedangkan nilai yang didapatkan pada 5 perlakuan dibawah 3 sehingga masih efisien.

\section{Efisiensi Pakan (EP)}

Efisiensi pakan dapat diartikan sebagai kemampuan ikan memanfaatkan pakanyang diberikan sehingga ikan dapat tumbuh dan berkembang dengan baik. Pakan uji yang digunakan dalam penelitian ini adalah penambahan tepung daun singkong terfermentasi menggunakan EM4 dengan menggunakan dosis yang berbeda pada setiap perlakuannya.

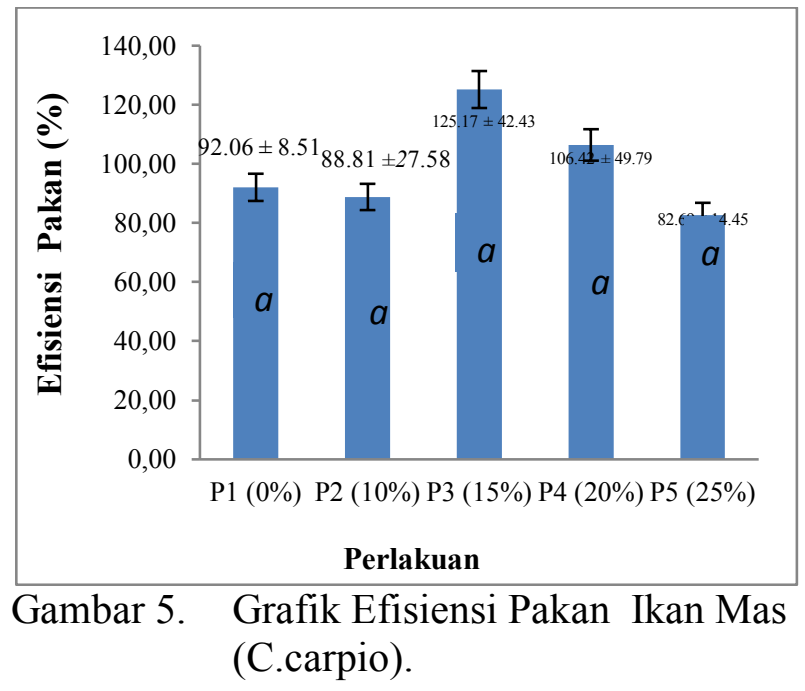

Hasil analisis sidik ragam menggunakan analisis keragaman satu arah (one way anova) didapat nilai efisiensi pakan tidak berbeda nyata dalam taraf kepercayaan 95\% ( $>00,05)$. Hasil uji menunjukan bahwa penambahan tepung daun singkong terfermentasi tidak memberikan pengaruh yang signifikan terhadap efisiensi pakan pada ikan mas.

Menurut pendapat Huet (1970), efisiensi pakan yang tinggi menunjukan 
penggunaan pakan yang efisisen, sehingga hanya sedikit protein yang dirombak untuk memenuhi kebutuhan energi dan selebihnya digunakan untuk pertumbuhan. Kualitas pakan yang baik adalah pakan yang memenuhi semua kebutuhan pakan ikan. Pakan yang berkualitas dapat dilihat berdasarkan kandungan nutrisinya yaitu protein, lemak, karbohidrat, mineral dan vitamin (Fujaya, 2004).

\section{Hasil Proksimat Bahan- bahan Pakan dan Pakan Percobaan}

Bahan-bahan yang digunakan dalam pembuatan pakan terdiri dari tepung ikan, tepung jagung, tepung tapioka dan tepung daun singkong yang sudah difermentasi menggunakan EM4. Pada penelitian ini hasil fermentasi tepung daun singkong digunakan sebagai bahan pengganti tepung ikan dan tepung jangung. Masing-masing bahan diuji proksimat terlebih dahulu untuk mngetahui nilai kadar protein, kadar air, kadar abu, lemak, karbohidrat dan serat kasar untuk menyesuaikan dengan komposisi dan formulasi pakan yang akan dibuat. Hasil proksimat lengkap disajikan pada Lampiran 1.

Hasil proksimat menunjukkan kandungan protein tepung ikan $64,93 \%$, tepung jagung sebesar 9,11\%, tepung tapioka sebesar $0,09 \%$ dan tepung daun singkong yang telah difermentasi menggunakan EM4 sebesar $29,20 \%$. Rendahnya protein tepung daun singkong dan protein tepung jagung juga harus di subtitusi, sehingga sesuai dengan protein $32 \%$ pakan komersil yang diberikan padaikan mas sebelumnya. Formuasi pakan dihitung menggunakan perhitungan Excel disajikan secara lengkap.

Menurut Listiowati (2014), daun singkong mengandung kadar protein yang cukup tinggi yaitu $27,28 \%$ protein kasar. Kandungan protein daun singkong umumnya berkisar antara 20-
36\% dari bahan kering. Kisaran ini disebabkan varietas, kesuburan tanah dan komposisi campuran daun dan tangkai daun. Dilihat dari tingginya serat kasar, daun singkong termasuk pakan sumber protein, disamping itu daun singkong mengandung vitamin A yang cukup tinggi (Askar, 1996). Protein tepung daun singkong dalam penelitian ini masih termasuk bagus, akan tetapi dilihat dari sisi kandungan serat kasar hasil tepung daun singkong fermentasi menggunakan EM4 tergolong mengandung serat kasar yang tinggi. Pada perlakuan penambahan tepung daun singkong terfermentasi P2 (10\%) kandungan serat kasarnya sebesar 7,55\%, perlakuan penambahan tepung daun singkong terfermentasi P3 (15\%) kandungan serat kasarnya sebesar 21,94\%, perlakuan penambahan tepung daun singkong terferemntasi P4 (20\%) kandungan serat kasarnya sebesar 24,21\%, perlakuan penambahan tepung daun singkong terfermentasi P5 (25\%) kandungan serat kasarnya sebesar 23,23\% dan kandungan serat kasar pada P1 (0\%) sebesar 6,26\% (Lampiran $3)$.

Serat kasar erat kaitannya dengan daya cerna ikan, semakin tinggi kandungan serat kasar pada pakan akan mempengaruhi daya cerna ikan. Serat kasar adalah bahan organik yang tidak larut dalam asam lemah dan basa lemah yang terdiri dari selulosa, hemiselulosa dan lignin (Putri et al., 2012)

\section{Kualitas Air}

Kualitas air merupakan salah satu faktor eksternal yang dapat mempengaruhi pertumbuhan ikan mas. Parameter kualitas lingkungan yang diukur selama penelitian dapat dilihat pada tabel dibawah ini

Tabel 1. Kualitas Air pemeliharaan selama penelitian 
Jurnal Perikanan (2021) Volume 11. No. 1 : 13-25

DOI : https://doi.org/10.29303/jp.v11i1.184

\begin{tabular}{ccccccc}
\hline Perlakuan & P1 & P2 & P3 & P4 & P5 & Pustaka \\
\hline Suhu & 28 & 27 & 28 & 27 & 27 & $14-38^{0} \mathrm{C}$ (Santoso, 1992) \\
DO & 4 & 3.6 & 3.7 & 3.6 & 4.3 & $>3 \mathrm{mg} / \mathrm{L}$ (Kartamihardja, 1981) \\
pH & 7.3 & 7.4 & 7.4 & 7.4 & 7.3 & $6.5-8.5$ (Pescod, 1973) \\
\hline
\end{tabular}

Hasil pengamatan suhu selama penelitian di daptkan kisaran $27^{0}-28^{\circ} \mathrm{C}$, dalam kondisi suhu perairan seperti itu masih dalam kisaran yang layak dalam budidaya ikan mas (Cyprinus carpio). Suhu juga berpengaruh terhadap tingkat nafsu makan ikan dan daya tahan terhadap penyakit. Menurut Gusman dan Muhammad (2014) yang menyatakan nilai kualitas air menunjukan bahwa parameter ini masih dalam batas kelayakan untuk kehidupan ikan mas. Kisaran kelayakaan air bagi ikan mas adalah $14^{0}-38^{\circ} \mathrm{C}$.

Oksigen terlarut atau Dissolved Oxygen (DO) merupakan salah satu variable penting dalam kualitas air. Hasil pengukuran oksigen terlarut selama penelitian didapatkan kisaran antara 3,6-4,3 mg/L. Kadar oksigen tersebut masih dalam kadar normal. Menurut Sulawesty et al., (2014) kandungan oksigen terlarut untuk pemeliharaan ikan mas adalah 2,5-7,1 $\mathrm{mg} / \mathrm{L}$. Menurut Rudiyanti Astir (2009), menyatakan bahwa kandungan oksigen dalam suatu perairan minimum sebesar $2 \mathrm{mg} / \mathrm{L}$, sudah cukup mendukung terhadap organisme perairan secara normal.

Nilai $\mathrm{pH}$ pada media pemeliharaan berkisar 7,3-7,4. Nilai $\mathrm{pH}$ tersebut masih dalam kisaran normal. Nilai $\mathrm{pH}$ suatu perairan dapat mempengaruhi pertubuhan bagi biota didalamnya, bahkan dapat menyebabkan kematian bagi biota tersebut. Hal ini didukung oleh Copatti et al., (2011) yang menyatakan bahwa $\mathrm{pH}$ netral dan sedikit alkali direkomendasikan untuk ikan air tawar. Hal ini didukung oleh Nirmala et al., (2012) bahwa pH mematikan bagi ikan adalah kurang dari 4 dan lebih dari 11, sedangkan $\mathrm{pH}$ yang 6,5 dan lebih dari 9,5 dalam beberapa jam akan mempengaruhi pertumbuhan dan produksi ikan.

\section{KESIMPULAN DAN SARAN}

Kesimpulan dari penelitian ini sebagai berikut: penambahan tepung daun singkong terfermentasi ke dalam pakan buatan memberikan pengaruh berbeda nyata $(\mathrm{P}<0,05)$ pada pertumbuhan mutlak dan laju pertumbuhan spesifik ikan mas (Cyprinus carpio), dan memberikan pengaruh yang tidak berbeda nyata $(\mathrm{P}>0,05)$ pada Survival rate, Rasio Konversi Pakan, dan Efisiensi Pakan.

Disarankan untuk penelitian selanjutnya dengan penambahan tepung daun singkong terfermentasi sebesar 10\% (P2) untuk nilai optimal terhadap ikan mas (Cyprinus carpio).

\section{DAFTAR PUSTAKA}

Amarwati, Subandiyono, Pinandyono. 2015. Pemanfaatan Tepung Daun Singkong (Manihot utilissima) yang Difermentasi Dalam Pakan Buatan Terhadap Pertumbuhan Benih Ikan Nila Merah (Oreochromis nilaticus). [Skripsi]. Program Studi Budidaya Perairan, Jurusan Perikanan, Fakultas Perikanan dan Ilmu Kelautan, UniversitasDiponegoro. Semarang.

AOAC. 1995. Official Methods of Analysis of The Association of Official Analytical Chemistry. Washington: AOAC. 
Jurnal Perikanan (2021) Volume 11. No. $1: 13-25$

DOI : https://doi.org/10.29303/jp.v11i1.184

Askar, S. 1996. Daun Singkong dan Pemanfaatannya Sebagai Pakan Tambahan. Balai Penelitian Ternak. Bogor. 5 (1): $21-25$

Copatti,C. E., Garcia, L. D.O. 2011. Low Water Hardness and $\mathrm{pH}$ Affect Growth and Survival of Silver Catfish Juveniles. Jurnal of The World Aquaculture society. Vol. 42. No. 4.

Direktorat Gizi Departemen Kesehatan RI. 1981. Daftar komposisi bahan makanan. Bharata Karya Aksara, Jakarta.

Fadri, S., Muchlisin. Z. A dan Sugito. 2016. Pertumbuhan, Kelangsungan Hidup dan Daya Cerna pada Ikan Nila (Oreochromis niloticus) yang Mengandung Tepung Daun Jaloh (Salix tetrasperma Roxb) dengan Penambahan Probiotik EM-4. Jurnal Ilmiah Mahasiswa Kelautan dan Perikanan Unsyiah. Vol. 3 (4) : 93-98.

Fujaya, Y. 2004. Fisiologi Ikan Dasar Pengembangan Teknik Perikanan. Cetakan Pertama. Rineka Putra. Jakarta. $165 \mathrm{hlm}$.

Effendi, H. 1997. Telaah Kualitas Air Bagi Pengelolaan Sumber Daya dan Lingkungan Perairan. Cetakan Kelima. Kanisius, Yogyakarta. $259 \mathrm{hlm}$.

Effendi, M. S. 2002. Biologi Perikanan. Cetakan Kedua. Yayasan Pustaka Nusantara, Yogyakarta, $163 \mathrm{hlm}$

Gusman, E. dan Muhammad Firdaus, 2014. Pemanfaatan Buah Mangrove sebagai Campuran Pakan untuk Meningkatkan Pertumbuhan Ikan Mas (Cyprinus carpio). Jurnal Harpodon Borneo. 07 (01): 27-35 hlm.
Halver, J. E. 1989. Fish Nutrition. Academic Press, Inc., Sandiego, California, USA. Vol. $2798 \mathrm{hlm}$.

Handajani, 2007. Optimalisasi Subtitusi Tepung Azolla Terfermentasi pada Pakan Ikan untuk Meningkatkan Produksi Ikan Nila Gift. Jurnal Teknik Industri, 12 (2) : 177-181.

Handajani, 2014. Peningkatan Nilai Nutrisi Tepung Azolla Melalui Fermentasi. Naskah Publikasi. Universitas Muhamadiyah Malang. Malang.

Hardjamulia, A. 1988. Budidaya Ikan Mas (Cyprinus carpio), Ikan Tawes (Puntius tetrazona), Ikan Nilem (Ostheochilus hasselti). Sekolah ilmu perikanan. SUPM. Bogor. Badan pendidikan, Latihan dan penyuluhan pertanian. Dept. Pertanian.

Harris, E. 2010. Peningkatan efisiensi pakan dan konversi limbah budidaya ikan menjadi produk ekonomis. Jurnal Akuakultur Indonesia.Vol.9 (2) : 196205.

Huet, M. 1970. Textbook of Firs Culture Breeding and Cultivation of Fish. Fishing News (Book Ltd), London. 436 p.

Irianto, A. 2005. Patologi Ikan Teleostei. Gadjah Mada Uneversity Press. Yogyakarta.

Khairuman, K, Amri. 2001. Buku Pintar Budidaya 15 Ikan Konsumsi. PT Agro Media Pustaka Jakarta.

Listiowati, E., T. B, Pramono. 2014. Potensi Pemanfaatan Daun Singkong (Manihot utilissima) Terfermentasi Sebagai Bahan Pakan Ikan Nila (Oreochromis sp). 
Jurnal Perikanan (2021) Volume 11. No. 1 : 13-25

DOI : https://doi.org/10.29303/jp.v11i1.184

Jurnal Berkala Perikanan Terubuk. Vol. 42. No. 3. 63-70 hlm.

Ng, W. K. dan Wee, K. L. 1989. The Nutritive Value of Cassava Leaf Meal in Pelleted Feed for Nile Tilapia. Aquaculture, 83 (1-2): 45-58.

NRC. 1993. Nutrition and Requirement of Warmwater Fishes. National Academic of Science Washington, D. C. $248 \mathrm{hlm}$.

Nurmala, K., Yani, H. dan Riza P. W. 2012. Penambahan Garam dalam Air Media yang Berisi Zeolit dan Arang Aktif pada Transportasi Sistem Tertutup Benih Ikan Gurami (Oshpronemus goramy Lac). Jurnal Akuakultur Indonesia. 11(02): 190-201 hlm.

Pescod, M. B.1973. Investigation of Rational Effluen and Stream Standard for Tropical Countries. London: AIT.

Priyadi, A., Z.I. Azwar., I.W. Subami dan S. Hem. 2009. Pemanfaatan maggot sebagai pengganti tepung ikan dalam pakan buatan untuk benih ikan balashark (Balanthiocheilus melanopterus Bleeker). Jurnal Riset Akuakultur.Vol. 4 (3) : 367-376.

Putri, D. R, Agustono, Sri S. 2012. Kandungan Bahan Kering, Serat Kasar dan Protein Kasar Pada Daun Lamtoro (Lucaena gluca) yang difermentasikan dengan probiotik sebagai Bahan Pakan Ikan. Jurnal Fakultas Perikanan dan Ilmu Kelautan. Universitas Erlangga Surabaya. 4 (2): 161-167

Purnamasari, D. K, Dilaga, S. H. 2015. Petunjuk praktikum landasan ilmu nutrisi. modul ilmu nutrisi dan makanan

ternak. Fakultas Peternakan Universitas Mataram. Mataram. 1-36.

Rahmad, D. Adelinadan Benny H. 2015. Pemanfaatan Fermentasi Daun Singkong (Manihot utilisima) dalam Pakan Buatan Terhadap Pertumbuhan dan Kelulusanhidup Benih Ikan Gurami (Osphronemus gouramy Lac). Fakultas Perikanan dan Ilmu Kelautan Universitas Riau. Riau 1-9.

Rika, N. P., A. Usman, S dan Maryati. 2016. Analisis rantai nilai pemasaran ikan air tawar di kabupaten Lombok Barat. Jurnal Agroteksos. 1-9.

Rudiyanti, S. dan Astri D. E., 2009. Pertumbuhan dan Survival rate Ikan Mas (Cyprinus carpio) pada Berbagai Konsentrasi Petisida Regent 0,3 G. Jurnal Saintek Perikanan. 05 (01): 39$47 \mathrm{hlm}$.

Sugiyono. 2012. Metode Penelitian Pendidikan Pendekatan Kuantitatif, Kualitatif, dan R\&D. Bandung ALFABETA. 2012 (cet.15).

Sulawesty F., Tjandra Chrismadhan, dan Endang Mulyana, 2014. Laju Pertumbuhan Ikan Mas (Chyprinus carpio) dengan Pemberian Pakan Lemna (Lemna Parpusilla Torr) Segar pada Kolam Sistem Aliran Tertutup. Jurnal Limnotek. 21(2): $177 \mathrm{hlm}$.

Sutriana, A, 2005. The Use of Caassava As A Dietary Componeant for African Catfish Fry. Jurnal Kedoktran Hewan Vol.1 (2).

Widyanti W. 2009. Kinerja Pertumbuhan Ikan Nila (Oreochromis notices) yang diberi 
Jurnal Perikanan (2021) Volume 11. No. 1 : 13-25

DOI : https://doi.org/10.29303/jp.v11i1.184

Berbagai Dosis Enzim Caira Rumen pada Pakan Berbasis Daun Lamtoro.[Skripsi]. Fakultas Perikanan dan Ilmu Kelautan. Institut Pertanian Bogor. Bogor. 68 hlm.

Widyastuti, Sukanto, Rukayah. 2010. Penggunaan Pakan Fermentasi Pada Budidaya Ikan Sistem Keramba Jaring Apung untuk Mengurangi Potensi Eutrofikasi di Waduk Wadaslintang. Limnotek 17 (2): 191-200
Widjanarko B. A., Pratiwi., dan C, Retnaningsih. 2000. Seri Iptek Pangan. Volume 1: Teknologi, Produk, Nutrisi dan keamanan Pangan. Jurusan Teknologi Pangan-Unika Soegijapranata. Semarang. $84 \mathrm{hlm}$.

Yudhitstira, S., Iskandar, Y., Andriani. 2015. Pengaruh Penggunaan Daun Apu-Apu (Pistia stratiotes) Fermentasi Dalam Pakan Terhadap Pertumbuhan Harian dan Rasio Konversi Pakan Benih Ikan Nila. Jurnal Akuatika.Vol. 5 (2) : 118127. ISSN: 0853-2532. 